\title{
MULTIPLE CRITERIA ASSESSMENT OF APARTMENT BUILDING PERFORMANCE FOR REFURBISHMENT PURPOSES
}

\author{
Laura TUPĖNAITE ${ }^{1}$, Artūras KAKLAUSKAS ${ }^{1, *}$, Igor VOITOV ${ }^{2}$, Vaidotas TRINKŪNAS ${ }^{1}$, \\ Nikolai SINIAK ${ }^{2}$, Renaldas GUDAUSKAS ${ }^{1}$, Jurga NAIMAVIČIENE ${ }^{1}$, \\ Loreta KANAPECKIENE $\dot{1}^{1}$ \\ ${ }^{1}$ Vilnius Gediminas Technical University, Sauletekio al. 11, LT-10223 Vilnius, Lithuania \\ ${ }^{2}$ Belarusian State Technological University, 13a Sverdlova str., 110006 Minsk, Belarus
}

Received 17 November 2016; accepted 3 July 2017

\begin{abstract}
The selection of buildings for refurbishment is a multi-objective problem and it should be based on integrated assessment of the current performance of the buildings. Accurate assessment allows the development of strategies for the optimisation of building performance and the selection of appropriate and most efficient refurbishment measures. This paper presents a computer-based integrated building performance assessment methodology based on the multiple-criteria approach. A case study from the Šiauliai district, Lithuania, illustrates the proposed methodology in use. The assessment results indicate what are the worst performing buildings and help with the selection of appropriate refurbishment measures and estimation of possible outcomes.
\end{abstract}

Keywords: apartment buildings, performance, multiple criteria assessment, COPRAS, refurbishment measures.

\section{Introduction}

Lithuania has the same energy efficiency goals as the rest of the European Union. Major energy efficiency and $\mathrm{CO}_{2}$ emission savings have to be achieved by 2050 . The housing sector is the second largest energy consumer in Lithuania, and one with a high saving potential. Certain actions, however, must be taken to be able to use this potential. Lithuania, as most European countries, experienced a post-war construction boom. More than $70 \%$ of the residential buildings in Lithuania were built between 1960 and 1993. The majority of the buildings are, therefore, in bad condition and currently require refurbishment.

Refurbishment is a rather slow process in Lithuania that requires technological, social and financial support. Financial refurbishment instruments today mostly rely on grants and subsidies. This fact of scope, combined with the fact that almost all apartment buildings are held by private ownership and over $50 \%$ of owners have to approve refurbishment, encumbers the whole process. Moreover, the refurbishment of buildings is co-financed by homeowners; it is a long and expensive process that requires transparency. To speed up the refurbishment process, accordingly, both a careful selection of projects and transparent explanation of expected refurbishment results are necessary. The selection of buildings for refurbishment is a multi-objective problem and it should be based on integrated assessment of the current performance of the buildings. Accurate assessment allows the development of strategies for building performance optimisation and the selection of appropriate and most efficient refurbishment measures.

The purpose of this paper is to develop computerbased integrated buildings' performance assessment methodologies based on a multiple-criteria approach. This paper is organised as follows: Section 1 presents a literature review, Section 2 describes a methodology for buildings' performance assessment, Section 3 illustrates the application of the proposed methodology in the Šiauliai district (Lithuania). Finally, conclusions are presented.

\section{Literature review}

Every product or process goes through various phases or stages in its life. Each stage is composed of a number of activities. For industrial products, these stages can be broadly defined as material acquisition, product design, manufacturing, use and maintenance, and end-of-life. In

${ }^{*}$ Corresponding author. E-mail: arturas.kaklauskas@vgtu.lt 
case of buildings, these stages are more precisely delineated by Bayer, Gamble, Gentry, and Joshi (2010) as material manufacturing, design, construction, use and maintenance and end of life (demolition).

Various studies (e.g. Caliskan, 2015; Zhang \& Wang, 2015; Chau, Hui, Ng, \& Powell, 2012; Uihlein \& Eder, 2010; Nemry et al., 2010) dealing with the analysis of building life cycle and its constituent parts have been performed worldwide. Many of the studies emphasize the importance of energy-efficient building refurbishment (Nicolae \& George-Vlad, 2015; Lasvaux et al., 2015; IbnMohammed, Greenough, Taylor, Ozawa-Meida, \& Acquaye, 2014; Rezaie, Dincer, \& Esmailzadeh, 2013, etc.).

The problem of selection of efficient refurbishment measures and scenarios was discussed by many authors from different countries, i.e. Kragh and Rose (2011) performed research on housing renovation in Denmark; Ouyang, Wang, Li, and Hokao (2011) in China; Brown, Malmqvist, Bai, and Molinari (2013) in Sweden; Baek, and Park (2012) in France, Germany, Denmark and Sweden; Mahapatra et al. (2013), Mlecnik et al. (2012) in the Nordic countries; Galvin (2012) in Germany; Ciulla, Lo Brano, and Orioli (2010) and Cellura et al. (2011) in Italy; Kanapeckiené, Kaklauskas, Zavadskas, and Raslanas (2011), Biekša, Šiupšinskas, Martinaitis, and Jaraminienè (2011), Kaklauskas, Tupenaitè, Kanapeckienè, and Naimavičienè (2013) in Lithuania.

Many decision support systems (DSS) for the refurbishment purposes have been developed worldwide: Kaklauskas et al. (2015) proposed multiple criteria DSS of the life cycle of the built environment; Juan, Kim, Roper, and Castro-Lacouture (2009) Genetic algorithm-based decision support system for housing condition assessment and refurbishment strategies; Ochoa and Capeluto (2015) an adaptable energy retrofit façade system for residential buildings; Uzomah, Scholz, and Almuktar (2014) - an expert tool for different professions based on estimated ecosystem variables for retrofitting of drainage system; Di Sivo and Ladiana (2011) - decision-support tools for municipal infrastructure maintenance management, etc.

An analysis of the aforementioned methodologies and decision support systems reveals that most of the authors usually focus on the estimation of refurbishment scenarios and measures. Achievement of energy efficient refurbishment results, however, directly depends on the initial condition and performance of the building.

Classification and certification of buildings differ from one country to another in accordance with national conditions and requirements. The sensitivity of methods and independence of indicators are progressively ensured with continuous modification and specification of methods and tools (Vilcekova \& Kridlova Burdova, 2014). The most commonly used building performance assessment method currently used in Europe is the Building Research Establishment Environmental Assessment Method (BREEAM). However, BREEAM requires a lot of detailed information to be implemented, and the procedure is fairly complicated
(Kabak, Köse, Kırılmaz, \& Burmaoğlu, 2014), moreover, the method is mostly used for environmental assessment and mostly for new buildings. For detailed assessment of old buildings' performance technical and functional obsolescence criteria must be considered. According to Hopfe, Augenbroe, and Hensen (2013), building performance assessment is complex, as it has to respond to multiple criteria. It, therefore, follows that buildings' performance assessment requires a multidisciplinary and multi-criteria approach.

\section{Methodology for the assessment of apartment building performance}

This study focuses on one of the stages of residential building performance assessment, namely the 'use and maintenance' phase. The building performance assessment for refurbishment purposes is treated as a multidisciplinary problem that requires a multiple criteria approach. This approach has been proved as efficient for governmental agencies. Kurth, Larkin, Keisler, and Linkov (2017) analysed trends and applications of multi-criteria decision analysis in government agencies. Authors concluded that there is an increase in awareness and consideration of MCDA from 2000 to the present, and that agencies are especially considering and using tools to engage with stakeholders.

Alternatives can be assessed using various Multiple Criteria Decision Analysis (MCDA) methods such as MAUT (Multi-Attribute Utility Theory), AHP (Analytic Hierarchy Process), SAW (Simple Additive Weighting), COPRAS (Multiple Criteria Proportional Assessment), TOPSIS (Technique for Order of Preference by Similarity to Ideal Solution), ELECTRE, etc.

An extensive review of the environmental applications of MCDA methods was performed by Huang, Keisler, and Linkov (2011). The authors identified over 300 papers published between 2000 and 2009 reporting on the use of MCDA in the environmental field. According to this study, MAUT, AHP and ELECTRE were the most common methods in restoration applications. More recently, approximately 3000 papers concerning multi-criteria decision analysis (MCDA) in the environmental field were identified by Cegan, Filion, Keisler, and Linkov (2017). The results show a linear growth in the share of MCDA papers in environmental science across all application areas. Furthermore, the results reveal that AHP/ANP and MAUT/MAVT are the most frequently mentioned MCDA methods in the literature.

It has been noted, however, by Huang et al. (2011), that MCDA approaches "are somewhat similar enough and the differences in the choice of their application may be based more on familiarity and available opportunities than solely on the merits of the different methods themselves".

For our case study, presented in Section 3, the COPRAS method was selected. The method was developed by scientists from Vilnius Gediminas Technical University 
Zavadskas and Kaklauskas in 1996. This method assumes direct and proportional dependence of significance and priority of investigated alternatives on a system of attributes. According to studies by Chatterjee, Athawale, and Chakraborty (2011), Zavadskas, Turskis, and Kildienė (2014), it is a rapidly developed method applied to reallife problem solving. Moreover, COPRAS was proved to be efficient for various refurbishment problems' solutions (Kaklauskas, Zavadskas, \& Raslanas, 2005; Kaklauskas et al., 2006; Kaklauskas, Zavadskas, \& Galiniené, 2008; Zavadskas \& Antuchevičienè, 2007; Banaitienè, Banaitis, Kaklauskas, \& Zavadskas, 2008; Tupenaite, 2010; Tupenaite, Zavadskas, Kaklauskas, Turskis, \& Seniut, 2010; Medineckienè \& Björk, 2011; Šiožinyte, Antuchevičienè, \& Kutut, 2014; Rasiulis, Ustinovichius, Vilutienè, \& Popov, 2016, etc.).

The methodology for the assessment of apartment building performance proposed by the authors is based on COPRAS and consists of eight interrelated stages (see Figure 1).

Stage 1. Development of initial decision-making matrix $P$ :

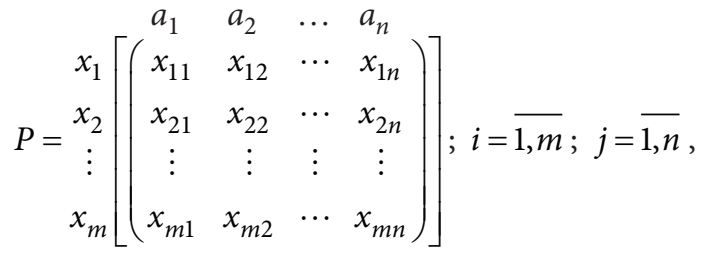

where: $a_{j}$ - alternative; $x_{i}$ - attribute; $n$ - number of considered apartment buildings' alternatives; $m$ - number of assessed performance attributes; $x_{i j}$ - the attribute value of the $j^{\text {th }}$ alternative.

Stage 2. Determination of the significances of attributes $\left(q_{i}\right)$ by experts. It is recommended to perform the survey of at least 10 experts. Sum of significances must be equal to 1 . Significance of the attribute is calculated by the following equation:

$$
q_{i}=\frac{s_{i}}{\sum_{i=1}^{r} s_{i}},
$$

where: $s_{i}$ - estimated significance of the $i^{\text {th }}$ attribute; $r$ number of experts.

Stage 3. The weighted normalized decision-making matrix $\hat{P}$ is constructed. The purpose of this stage is to receive dimensionless weighted values of the attributes. All attributes, originally having different dimensions, can be compared when their dimensionless values are known. The following equation is used:

$$
\hat{x}_{i j}=\frac{x_{i j} \cdot q_{i}}{\sum_{j=1}^{n} x_{i j}} ; i=\overline{1, m} ; j=\overline{1, n},
$$

where: $n$ - number of alternatives; $m$ - number of attributes; $x_{i j}$ - the attribute value of the $j^{\text {th }}$ alternative; $q_{i}$ - significance (weight) of the $i^{\text {th }}$ attribute.

The sum of dimensionless weighted index values $\hat{x}_{i j}$ of each attribute is always equal to the significance $q_{i}$ of this attribute:

$$
q_{i}=\sum_{j=1}^{n} \hat{x}_{i j} ; i=\overline{1, m} ; j=\overline{1, n} .
$$

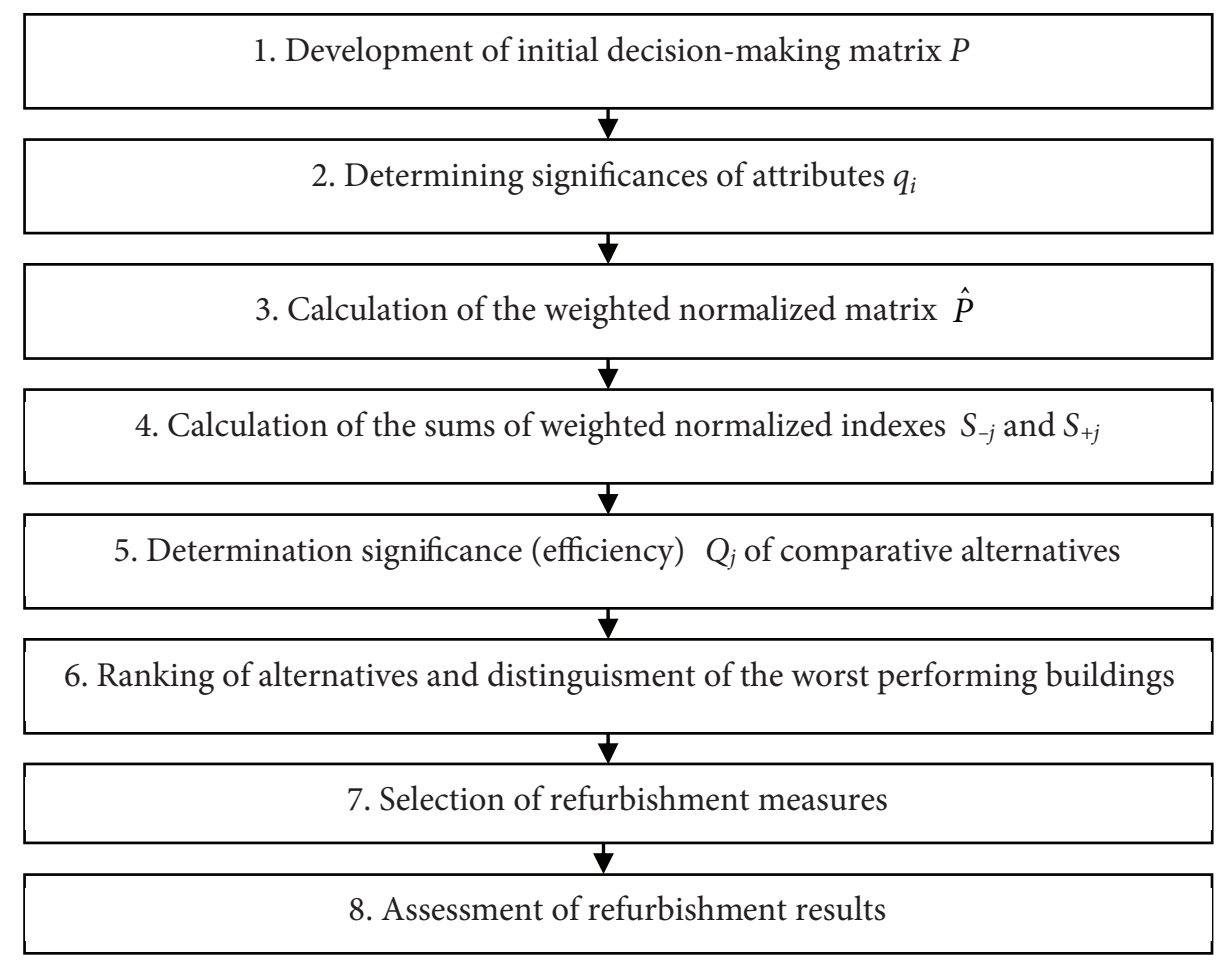

Figure 1. Multiple criteria assessment of buildings' performance based on COPRAS method 
In other words, the value of significance $q_{i}$ of the investigated attribute is proportionally distributed among all alternative versions $a_{j}$ according to their values $x_{i j}$.

Stage 4 . The sums of weighted normalized indexes describing the $j^{\text {th }}$ alternative are calculated. The options are described by minimizing attributes $S_{-j}$ and maximizing attributes $S_{+j}$. The sums are calculated according to the formula:

$$
S_{+j}=\sum_{i=1}^{m} \hat{x}_{+i j} ; S_{-j}=\sum_{i=1}^{m} \hat{x}_{-i j} ; i=\overline{1, m} ; j=\overline{1, n} .
$$

In this case, the values $S_{+j}$ (the greater is this value, the better is performance of the building) and $S_{-j}$ (the lower is this value, the worse is performance of the building) express the general condition of each building alternative. In any case the sums of "pluses" $S_{+j}$ and "minuses" $S_{-j}$ of all alternative buildings are always respectively equal to all sums of significances of maximized and minimized attributes:

$$
\begin{aligned}
& S_{+}=\sum_{j=1}^{n} S_{+j}=\sum_{i=1}^{m} \sum_{j=1}^{n} \hat{x}_{+i j}, \\
& S_{-}=\sum_{j=1}^{n} S_{-j}=\sum_{i=1}^{m} \sum_{j=1}^{n} \hat{x}_{-i j} ; i=\overline{1, m} ; j=\overline{1, n} .
\end{aligned}
$$

In this way, the calculations made may be additionally checked.

Stage 5. The significance (efficiency) of comparative alternatives is determined on the basis of describing positive (pluses) and negative (minuses) characteristics. Relative significance $Q_{j}$ of each alternative $a_{j}$ is found according to the formula:

$$
Q_{j}=S_{+j}+\frac{S_{-\min } \cdot \sum_{j=1}^{n} S_{-j}}{S_{-j} \cdot \sum_{j=1}^{n} \frac{S_{-\min }}{S_{-j}}} ; j=\overline{1, n} .
$$

Stage 6. Determining the priority order of buildings' alternatives. The greater the $Q_{j}$, the higher is the efficiency of an alternative and vice versa.

In order to visually assess alternative efficiency, the utility degree $N_{j}$ can be calculated. The degree of utility is determined by comparing the analyzed alternative with the most efficient alternative. In this case, all the utility degree values related to the analyzed alternative will be ranged from $0 \%$ to 100 (Kaklauskas, 1999):

$$
N_{j}=\frac{Q_{j}}{Q_{\max }} \cdot 100 \% .
$$

Calculated degree of utility allows distinguishing buildings' alternatives that perform worst. In order to achieve the highest refurbishment results worst performing alternatives are in priority order for refurbishment.

Stage 7. Analysis of worst performing buildings' characteristics is performed and corresponding refurbishment measures are selected.

Stage 8. Predictive calculations of potential energy savings and reduction of greenhouse gas (GHG) emissions.
The proposed model is based on the COPRAS method and may have accuracy limitations that are particular to the MCDA methods.

The authors of this paper study the assessment of building performance attribute values; the selection of buildings to be refurbished, thus, depends on the accuracy of measurements. If the measurements are not accurate, the result produced will not be accurate either. An important step in many environmental applications of MCDA is, therefore, to perform a sensitivity analysis of the input data (Linkov \& Moberg, 2012). Saltelli et al. (2008) proposed the following definition of sensitivity analysis: "The study of how uncertainty in the output of a model (numerical or otherwise) can be apportioned to different sources of uncertainty in the model input".

To assess the robustness of the alternatives, the Monte Carlo method is applied. This method is commonly used in the modelling of physical and mathematical systems, when a deterministic algorithm cannot produce accurate results.

A look at studies by other researchers who applied the Monte Carlo method reveals that uniform and normal distributions are the most common in data generation (Sakalauskas \& Žilinskas, 2006; Mun, 2006). Thus data variance according to the uniform distribution law $X \sim U(a, b)$ and the normal distribution law $X \sim N(\mu, \sigma)$ is researched.

The sensitivity analysis can be performed using the proposed algorithm (see Figure 2).

1. Development of the initial matrix

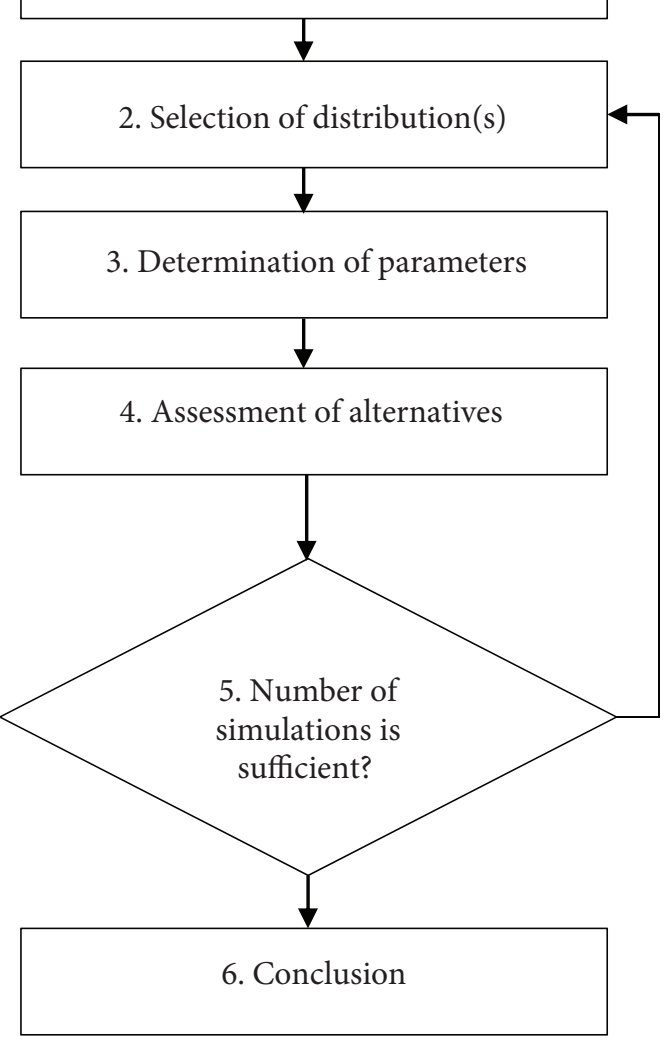

Figure 2. Algorithm for sensitivity analysis 
The sensitivity analysis comprises of the following steps:

1) Based on the decision model developed by the authors, a decision matrix is created. The matrix reflects the practical results of the evaluations and contains the attribute significances and attribute values of the alternatives (buildings);

2) The distribution to generate the attribute values of the alternatives is selected;

3) The initial parameters (the number of matrixes to be generated, the range of random variables or the average deviation) are determined;

4) The alternatives are ranked by priority in each case by using the COPRAS method;

5) Verification whether the number of simulations is sufficient to produce reliable results;

6) Conclusions on the sensitivity. If the model and calculation results are accurate enough (the sensitivity is low), the results can be used in the next step - the selection of the refurbishment measures.

\section{Case study}

\subsection{Background}

The first step in preparing for refurbishment is the integrated assessment of the current condition of the buildings. As discussed previously, integrated assessment must be based on a comprehensive system of criteria.

For our assessment task, five different properties (apartment buildings) were selected, all in Šiauliai district, Lithuania. The Šiauliai is the fourth largest city in Lithuania. During WWII a significant part of the city was destroyed and the majority of the buildings were re-built during the Soviet times. These buildings are currently still in use but are energy inefficient and do no longer meet other requirements. Therefore, it is important to make proper decisions which of the buildings need refurbishment first.

In Šiauliai, the refurbishment concept is focused on the building stock with very low energy efficiency and poor structural conditions. The description of the five alternative buildings is provided in Table 1 .

Table 1. Description of alternatives

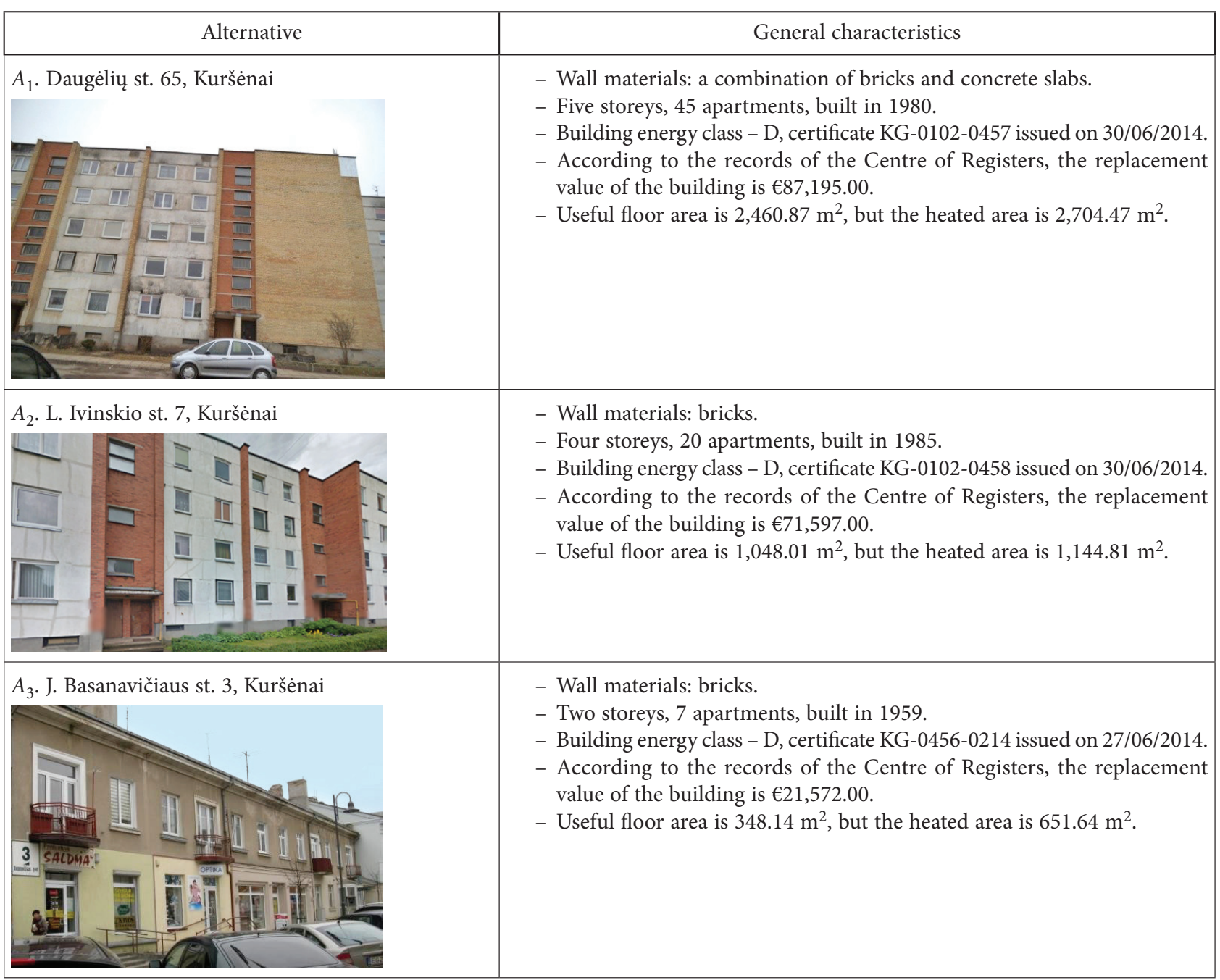


End of Table 1

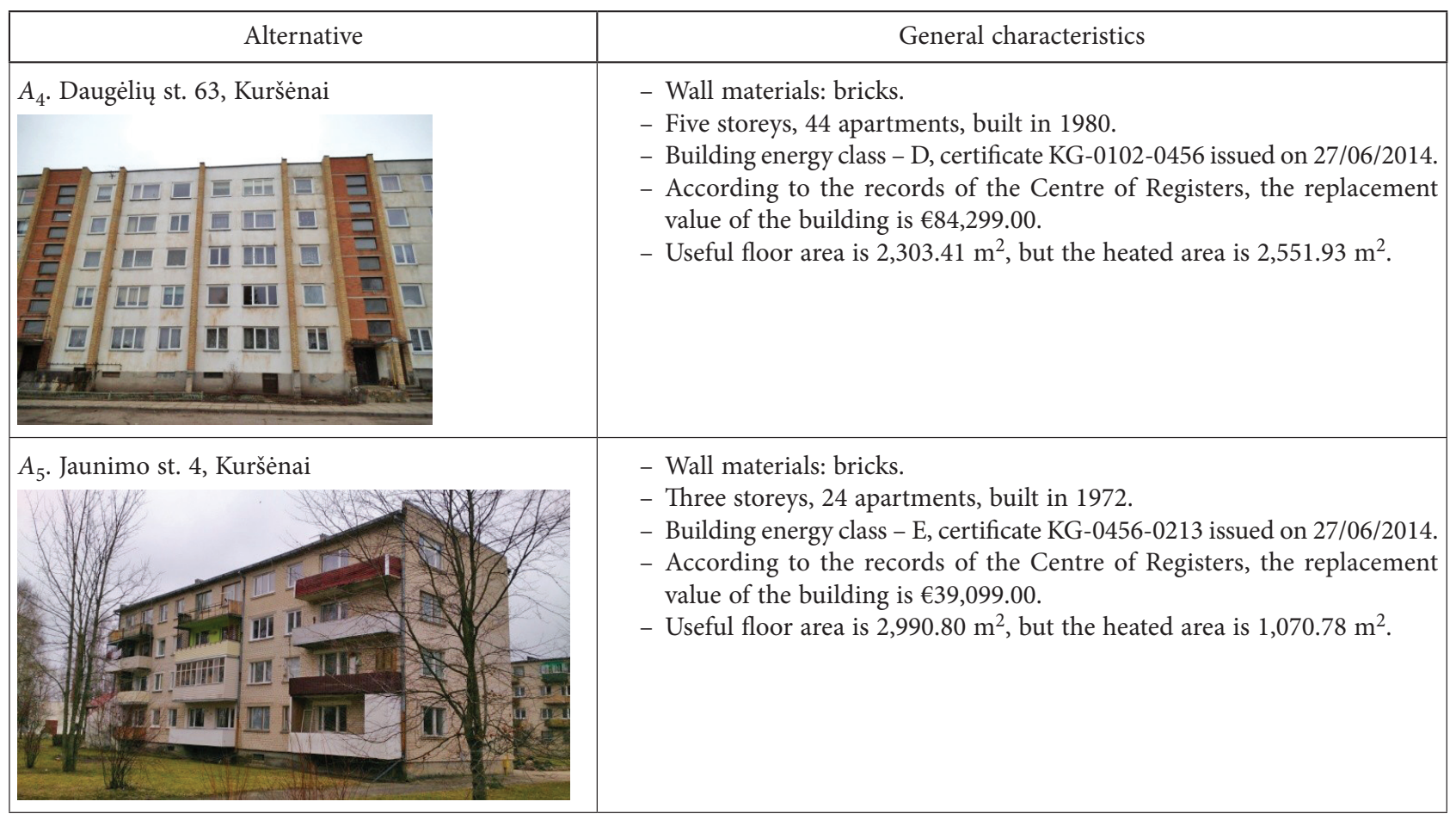

In order to assess the condition of the five alternative buildings, a system of criteria was developed in line with the Preparation Procedure for Renovation (Modernization) Projects approved by the Minister of the Environment of the Republic of Lithuania (2009).

The following criteria were applied in the assessment: the replacement value, year of construction, the energy performance class, the heat demand per square meter of useful floor area, greenhouse gas emissions and the physical and technical condition of structures and utilities (façade walls, foundations and perimeter walks, roofs, windows and balcony doors, balcony load-bearing structures, basement ceiling structures, windows and entrance doors in stairways and other common areas, heating systems, hot water supply systems, cold water supply systems, sewerage systems, ventilation systems and power supply systems).

Ten experts from Vilnius Gediminas Technical University, two professors and eight associate professors, all with $\mathrm{PhDs}$ in technological sciences (civil engineering), were surveyed to determine the criteria weights. The experts were briefed and had to complete a questionnaire assessing each criterion on a 10 -point scale, where 10 means a very important criterion and 1 means an insignificant criterion. Table 2 lists the estimated weights of the criteria.

The physical and technical conditions of structures and utilities were assessed on a four-points scale, with 4 for good condition, 3 for satisfactory condition, 2 for bad condition (needs repairs in the next couple of years), and 1 for poor condition (needs immediate repairs - threat to human lives or likely hefty economic loss caused by further damage to the building). The methodology recommended in the Preparation Procedure for Renovation
(Modernization) Projects approved by the Minister of the Environment of the Republic of Lithuania (2009) was used for assessment purposes.

As part of the assessment of the physical and technical condition of their structures and utilities, all alternatives were compared. Alternative 1 and Alternative 4 were constructed from reinforced concrete slabs and bricks. The façade walls display damage with spots of crumbled off finish, vertical splits, cracks and damage to load-bearing masonry structures. Alternatives 2, 3 and 5 have masonry wall structures as well. All buildings have issues with walls regularly getting wet because of bad rainwater drainage or exposure to wind and precipitation. This leads to uneven, patchy appearance with the surface layer showing signs of failure and cracks. In all blocks of flats, the thermal resistance of the walls is outside the norms. If we look at the condition of the foundations and perimeter walks, all alternatives have strip foundations with perimeter walks in bad repair (cracked, missing in places) and visible gaps between the perimeter walk and the foundation. Bad rainwater drainage means that the foundations are constantly exposed to moisture, which is a threat to the load carrying capacity of the building. Alternatives 3-5 have patches with plaster crumbled off on their bases.

All alternatives assessed have flat roofs with bitumen roofing, the only exception being the block of flats at Daugelių st. 65 (Alternative 3) which has a slanting roof covered with asbestos cement corrugated sheets. The flat roofs have random air pockets on their roofing and no extra layer of thermal insulation, damaged structure of the roof vent pipes, and signs of corrosion on the metal parapet capping, which is of bad quality. The thermal 
Table 2. Estimation of criteria significances

\begin{tabular}{|c|c|c|c|c|c|c|c|c|c|c|c|c|}
\hline \multirow{2}{*}{ Criterion } & \multicolumn{10}{|c|}{ Expert } & \multirow{2}{*}{ Sum } & \multirow{2}{*}{ Weight* } \\
\hline & 1 & 2 & 3 & 4 & 5 & 6 & 7 & 8 & 9 & 10 & & \\
\hline Replacement value of the house & 9 & 6 & 10 & 6 & 7 & 6 & 5 & 8 & 5 & 8 & 70 & 0.054432 \\
\hline Year of construction & 7 & 8 & 10 & 10 & 5 & 8 & 6 & 8 & 10 & 9 & 81 & 0.062986 \\
\hline Energy efficiency class & 6 & 8 & 10 & 10 & 3 & 10 & 4 & 10 & 9 & 9 & 79 & 0.061431 \\
\hline $\begin{array}{l}\text { Heat energy consumption per sq. m. of useful } \\
\text { area }\end{array}$ & 6 & 4 & 10 & 10 & 8 & 8 & 3 & 9 & 10 & 9 & 77 & 0.059876 \\
\hline Greenhouse gas (GHG) emissions & 1 & 2 & 9 & 7 & 4 & 6 & 9 & 10 & 8 & 8 & 64 & 0.049767 \\
\hline Condition of foundations and pavement & 7 & 7 & 9 & 8 & 5 & 7 & 8 & 10 & 10 & 9 & 80 & 0.062208 \\
\hline Condition of façade walls & 7 & 9 & 8 & 8 & 5 & 8 & 5 & 10 & 8 & 9 & 77 & 0.059876 \\
\hline Condition of roof & 7 & 7 & 10 & 7 & 7 & 8 & 6 & 10 & 9 & 7 & 78 & 0.060653 \\
\hline $\begin{array}{l}\text { Condition of windows and balcony doors in } \\
\text { apartments }\end{array}$ & 5 & 6 & 10 & 6 & 8 & 8 & 6 & 10 & 5 & 6 & 70 & 0.054432 \\
\hline Condition of balconies and loggias structures & 7 & 5 & 10 & 9 & 5 & 7 & 7 & 10 & 10 & 6 & 76 & 0.059098 \\
\hline Condition of the basement slab & 5 & 7 & 8 & 7 & 6 & 5 & 7 & 9 & 9 & 9 & 72 & 0.055988 \\
\hline $\begin{array}{l}\text { Condition of windows and exterior entrance } \\
\text { doors in hallways and other common areas }\end{array}$ & 4 & 7 & 8 & 6 & 8 & 5 & 3 & 8 & 8 & 5 & 62 & 0.048212 \\
\hline Condition of heating system & 7 & 8 & 10 & 8 & 7 & 7 & 9 & 10 & 10 & 9 & 85 & 0.066096 \\
\hline $\begin{array}{l}\text { Condition of cold and hot water supply } \\
\text { engineering system }\end{array}$ & 4 & 8 & 10 & 8 & 6 & 7 & 9 & 10 & 10 & 7 & 79 & 0.061431 \\
\hline $\begin{array}{l}\text { Condition of sewage disposal engineering } \\
\text { system }\end{array}$ & 5 & 7 & 10 & 8 & 7 & 7 & 9 & 10 & 10 & 7 & 80 & 0.062208 \\
\hline Condition of ventilation system & 5 & 7 & 9 & 8 & 3 & 10 & 9 & 9 & 9 & 7 & 76 & 0.059098 \\
\hline $\begin{array}{l}\text { Condition of general electrical engineering } \\
\text { system }\end{array}$ & 5 & 7 & 10 & 9 & 6 & 7 & 9 & 10 & 10 & 7 & 80 & 0.062208 \\
\hline & & & & & & & & & & & 1286 & 1 \\
\hline
\end{tabular}

Note: ${ }^{*}$ - calculated according to Equation (2)

resistance of all flat roofs is outside the norms. The capping of the slanting roof is also corroded in places and the structure of the roof vent pipes is damaged due to badly installed capping. Alternatives 3 and 5 have external rainwater drainage systems with corroded gutters.

The analysis of the condition of windows and balcony doors shows that in all blocks of flats the majority of windows were replaced with multi-chambered PVC profiles; they are in good condition. Those old wooden windows and balcony doors that remain are in bad condition with their thermal resistance outside the norms. If we take a look at the load-bearing structures of the balconies, in the first block of flats the structures are in critical condition. The load-bearing structures of the balconies are weathered, corroded and with their cladding crumbled off. The second block of flats, in contrast, displays no critical deformations, but the balcony railings are obsolete and show physical wear. The balconies in the third and the fifth building are of an open type with no critical deformations visible. In the fourth building, the majority of the balconies have been fully glazed in a chaotic manner, creating an ugly overall look of the façade. Old wooden profiles and PVC profiles dominate, but no critical deformations are visible.
In all alternatives assessed, the reinforced concrete basement ceilings have no thermal insulation and their heat transfer coefficient is outside the norms. None of the basements has heating. The windows and entrance doors in the stairways and other common areas are of similar condition in all blocks of flats. The majority of windows in the stairways and doors in the common areas are old and wooden and in bad condition. The infiltration of cold outdoor air into heated stairways is a cause of heat loss. Some windows and doors, though, have already been replaced with new ones. The situation is similar with basement windows and doors: some basement windows and doors have already been replaced, but those old wooden windows and doors that remain are of poor quality and their thermal resistance is outside the norms.

Analysis of the heating systems shows that all blocks of flats are connected to the district heating network and have heating systems with two-stage plate heat exchangers for hot water supply, and one-pipe heat supply systems with bottom distribution and automatic control. In all blocks of flats, the majority of the main pipes are damaged by corrosion. In Alternatives 1, 4 and 5, the insulation is poor - a cause of major heat loss. In Alternative 2, mixed thermal insulation has been installed. In Alternative 3 , the pipelines have been insulated with new thermal 
insulation. Alternatives 3 and 4 have outdoor temperature sensors installed. A comparison of the condition of the cut-off fittings of the heating systems shows that they have recently been replaced in Alternative 2 and work properly. Only some have been replaced in Alternative 3, while the heating systems in Alternatives 4 and 5 have old and corroded cut-off fittings. In Alternative 1, the majority of the cut-off fittings do not work. Of note is the fact that Alternatives 3, 4 and 5 have unbalanced systems, which prevents their functioning well.

All blocks of flats use their heating systems and plate heat exchangers for hot water supply, except for Alternative 5 , where individual boilers supply hot water. In all blocks of flats with plate heat exchangers, the system's pipes are damaged by corrosion and have bad or damaged insulation. Only in Alternative 2 some of the pipes have been replaced with new PVC pipes and in Alternative 3 some of the pipes have been insulated with new thermal insulation.

The comparison of the cold water supply systems shows that all blocks of flats get cold water from the centralised water supply system. In Alternatives 1 and 4, the system's pipes are damaged by corrosion. In Alternative 2 some of the pipes have been replaced with new PVC pipes, while in Alternatives 3 and 5 all main pipes were replaced with PVC pipes. In Alternative 3, however, they have no insulation, while in Alternative 5 they have foam wrap for insulation. Some of the cut-off fittings have been replaced in Alternative 3, and all have been replaced with new ones in Alternative 5. In Alternative 4, the cut-off fittings are old and corroded, which prevents their functioning well.
In all blocks of flats the sewerage systems use cast iron pipes, which are leaky. The build-up of deposits reduced the diameter of the pipes and that affects their capacity. In Alternatives 1,2 and 4, some of the sewer pipes have been replaced with new PVC pipes.

All blocks of flats use natural ventilation: air flows in through windows and doors and flows out through vertical ventilation ducts. The air change in indoor spaces is, however, insufficient.

If we compare the power supply systems, all blocks of flats have the electrical wiring with aluminium wires in their common areas. In Alternative 1 and 2, the power distribution boards are in poor condition; new automatic stairway lighting has been installed in Alternative 5.

\subsection{Multiple criteria assessment of buildings' performance}

With all the initial data and attributes' significances and values available, a computer-aided system, based on COPRAS method, was developed. It is available at: http://iti.vgtu.lt/ilearning/daugkrit.aspx? sistemid $=771$.

The qualitative and quantitative description of alternatives according to selected attributes is provided in Table 3 .

Results of multiple criteria evaluation of buildings' alternatives are provided in Table 4. Analysis revealed that the best performing is Alternative 2 (L. Ivinskio st. 7, Kuršėnai) and the worst performing are Alternative 5 (Jaunimo st. 4, Kuršènai) and Alternative 1 (Daugèlių st. 65, Kuršènai). The worst performing buildings shall be renovated.

Table 3. Qualitative and quantitative description of the alternatives

\begin{tabular}{|c|c|c|c|c|c|c|c|c|}
\hline \multicolumn{9}{|c|}{ Quantitative and qualitative information pertinent to alternatives } \\
\hline \multirow[b]{2}{*}{$\begin{array}{l}\text { Criteria describing the } \\
\text { alternatives }\end{array}$} & \multirow[b]{2}{*}{ * } & \multirow[b]{2}{*}{$\begin{array}{l}\text { Measuring } \\
\text { units }\end{array}$} & \multirow[b]{2}{*}{ Weight } & \multicolumn{5}{|c|}{ Compared alternatives } \\
\hline & & & & $\begin{array}{l}\text { Alternative } \\
\text { No. } 1 \\
\text { (Daugèlių } \\
\text { str. 65) }\end{array}$ & $\begin{array}{l}\text { Alternative } \\
\text { No. } 2 \\
\text { (L. Ivinskio } \\
\text { str. 7) }\end{array}$ & $\begin{array}{c}\text { Alternative } \\
\text { No. } 3 \\
\text { (J. Basanavičiaus } \\
\text { str. 3) }\end{array}$ & $\begin{array}{l}\text { Alternative } \\
\text { No. } 4 \\
\text { (V. Daugèlių } \\
\text { str. 63) }\end{array}$ & $\begin{array}{l}\text { Alternative } \\
\text { No. } 5 \\
\text { (Jaunimo } \\
\text { str. 4) }\end{array}$ \\
\hline $\begin{array}{l}\text { Replacement value of } \\
\text { the house }\end{array}$ & + & $\mathrm{EUR} / \mathrm{m}^{2}$ & 0.0544 & 3224 & 6254 & 3310 & 3303 & 3651 \\
\hline Year of construction & + & Year & 0.0630 & 1980 & 1985 & 1959 & 1980 & 1972 \\
\hline Energy efficiency class & + & Points & 0.0614 & 4 & 4 & 4 & 4 & 3 \\
\hline $\begin{array}{l}\text { Heat energy } \\
\text { consumption per sq. m. } \\
\text { of useful area }\end{array}$ & - & $\begin{array}{l}\mathrm{kWh} / \mathrm{m}^{2} \\
\text { per year }\end{array}$ & 0.0599 & 15974 & 16575 & 27671 & 16759 & 18844 \\
\hline $\begin{array}{l}\text { Greenhouse gas (GHG) } \\
\text { emissions }\end{array}$ & - & $\begin{array}{c}\mathrm{CO}_{2} \text { eq. per } \\
\text { year }\end{array}$ & 0.0498 & 2562 & 1419 & 11523 & 23724 & 16878 \\
\hline $\begin{array}{l}\text { Condition of } \\
\text { foundations } \\
\text { and pavement }\end{array}$ & + & Points & 0.0622 & 2 & 2 & 2 & 2 & 2 \\
\hline $\begin{array}{l}\text { Condition of façade } \\
\text { walls }\end{array}$ & + & Points & 0.0599 & 2 & 2 & 2 & 2 & 2 \\
\hline Condition of roof & + & Points & 0.0607 & 2 & 2 & 2 & 2 & 2 \\
\hline $\begin{array}{l}\text { Condition of balconies } \\
\text { and loggias structures }\end{array}$ & + & Points & 0.0591 & 2 & 2 & 3 & 3 & 3 \\
\hline $\begin{array}{l}\text { Condition of the } \\
\text { basement slab }\end{array}$ & + & Points & 0.0560 & 2 & 2 & 2 & 2 & 2 \\
\hline
\end{tabular}


End of Table 3

\begin{tabular}{|c|c|c|c|c|c|c|c|c|}
\hline \multicolumn{9}{|c|}{ Quantitative and qualitative information pertinent to alternatives } \\
\hline \multirow[b]{2}{*}{$\begin{array}{l}\text { Criteria describing the } \\
\text { alternatives }\end{array}$} & \multirow[b]{2}{*}{ * } & \multirow[b]{2}{*}{$\begin{array}{l}\text { Measuring } \\
\text { units }\end{array}$} & \multirow[b]{2}{*}{ Weight } & \multicolumn{5}{|c|}{ Compared alternatives } \\
\hline & & & & $\begin{array}{l}\text { Alternative } \\
\text { No. 1 } \\
\text { (Daugèlių } \\
\text { str. 65) }\end{array}$ & $\begin{array}{l}\text { Alternative } \\
\quad \text { No. } 2 \\
\text { (L. Ivinskio } \\
\quad \text { str. 7) }\end{array}$ & $\begin{array}{c}\text { Alternative } \\
\text { No. } 3 \\
\text { (J. Basanavičiaus } \\
\text { str. 3) }\end{array}$ & $\begin{array}{l}\text { Alternative } \\
\text { No. } 4 \\
\text { (V. Daugèlių } \\
\text { str. 63) }\end{array}$ & $\begin{array}{l}\text { Alternative } \\
\text { No. } 5 \\
\text { (Jaunimo } \\
\text { str. 4) }\end{array}$ \\
\hline $\begin{array}{l}\text { Condition of windows } \\
\text { and exterior entrance } \\
\text { doors in hallways and } \\
\text { other common areas }\end{array}$ & + & Points & 0.0482 & 2 & 2 & 3 & 3 & 2 \\
\hline $\begin{array}{l}\text { Condition of heating } \\
\text { system }\end{array}$ & + & Points & 0.066 & 3 & 3 & 3 & 3 & 3 \\
\hline $\begin{array}{l}\text { Condition of cold } \\
\text { and hot water supply } \\
\text { engineering system }\end{array}$ & + & Points & 0.0614 & 2 & 2 & 3 & 3 & 3 \\
\hline $\begin{array}{l}\text { Condition of sewage } \\
\text { disposal engineering } \\
\text { system }\end{array}$ & + & Points & 0.0622 & 2 & 2 & 3 & 3 & 3 \\
\hline $\begin{array}{l}\text { Condition of ventilation } \\
\text { system }\end{array}$ & + & Points & 0.0591 & 2 & 2 & 3 & 3 & 3 \\
\hline $\begin{array}{l}\text { Condition of general } \\
\text { electrical engineering } \\
\text { system }\end{array}$ & + & Points & 0.0622 & 2 & 2 & 3 & 3 & 3 \\
\hline $\begin{array}{l}\text { Condition of windows } \\
\text { and balcony doors in } \\
\text { apartments }\end{array}$ & + & Points & 0.0544 & 3 & 3 & 3 & 3 & 2 \\
\hline
\end{tabular}

Note: ${ }^{*}$ The sign $+(-)$ indicates that a greater (lesser) criterion value corresponds to a greater (lesser) significance for stakeholders

Table 4. Results of the multiple criteria evaluation of alternatives

Quantitative and qualitative information pertinent to alternatives

\begin{tabular}{|c|c|c|c|c|c|c|c|c|}
\hline \multicolumn{9}{|c|}{ Quantitative and qualitative information pertinent to alternatives } \\
\hline \multirow[b]{2}{*}{$\begin{array}{l}\text { Criteria describing the } \\
\text { alternatives }\end{array}$} & \multirow[b]{2}{*}{ * } & \multirow[b]{2}{*}{$\begin{array}{l}\text { Measuring } \\
\text { units }\end{array}$} & \multirow[b]{2}{*}{ Weight } & \multicolumn{5}{|c|}{ Compared alternatives } \\
\hline & & & & $\begin{array}{l}\text { Alternative } \\
\text { No. 1 } \\
\text { (Daugèlių } \\
\text { str. 65) }\end{array}$ & $\begin{array}{l}\text { Alternative } \\
\quad \text { No. } 2 \\
\text { (L. Ivinskio } \\
\text { str. 7) }\end{array}$ & $\begin{array}{c}\text { Alternative } \\
\text { No. } 3 \\
\text { (J. Basanavičiaus } \\
\text { str. 3) }\end{array}$ & $\begin{array}{l}\text { Alternative } \\
\text { No. } 4 \\
\text { (V. Daugèlių } \\
\text { str. 63) }\end{array}$ & $\begin{array}{l}\text { Alternative } \\
\text { No. } 5 \\
\text { (Jaunimo } \\
\text { str. 4) }\end{array}$ \\
\hline $\begin{array}{l}\text { Replacement value of the } \\
\text { house }\end{array}$ & + & $\mathrm{EUR} / \mathrm{m}^{2}$ & 0.0544 & 0.0089 & 0.0172 & 0.0091 & 0.0091 & 0.0101 \\
\hline Year of construction & + & Year & 0.0630 & 0.0126 & 0.0127 & 0.0125 & 0.0126 & 0.0126 \\
\hline Energy efficiency class & + & Points & 0.0614 & 0.0129 & 0.0129 & 0.0129 & 0.0129 & 0.0097 \\
\hline $\begin{array}{l}\text { Heat energy consumption } \\
\text { per sq. m. of useful area }\end{array}$ & - & $\begin{array}{l}\mathrm{kWh} / \mathrm{m}^{2} \\
\text { per year }\end{array}$ & 0.0599 & 0.01 & 0.0104 & 0.0173 & 0.0105 & 0.0118 \\
\hline $\begin{array}{l}\text { Greenhouse gas (GHG) } \\
\text { emissions }\end{array}$ & - & $\begin{array}{c}\mathrm{CO}_{2} \text { eq. per } \\
\text { year }\end{array}$ & 0.0498 & 0.0023 & 0.0013 & 0.0102 & 0.021 & 0.015 \\
\hline $\begin{array}{l}\text { Condition of foundations } \\
\text { and pavement }\end{array}$ & + & Points & 0.0622 & 0.0124 & 0.0124 & 0.0124 & 0.0124 & 0.0124 \\
\hline Condition of façade walls & + & Points & 0.0599 & 0.012 & 0.012 & 0.012 & 0.012 & 0.012 \\
\hline Condition of roof & + & Points & 0.0607 & 0.0121 & 0.0121 & 0.0121 & 0.0121 & 0.0121 \\
\hline $\begin{array}{l}\text { Condition of balconies } \\
\text { and loggias structures }\end{array}$ & + & Points & 0.0591 & 0.0091 & 0.0091 & 0.0136 & 0.0136 & 0.0136 \\
\hline $\begin{array}{l}\text { Condition of the } \\
\text { basement slab }\end{array}$ & + & Points & 0.0560 & 0.0112 & 0.0112 & 0.0112 & 0.0112 & 0.0112 \\
\hline $\begin{array}{l}\text { Condition of windows } \\
\text { and exterior entrance } \\
\text { doors in hallways and } \\
\text { other common areas }\end{array}$ & + & Points & 0.0482 & 0.008 & 0.008 & 0.0121 & 0.0121 & 0.008 \\
\hline
\end{tabular}


End of Table 4

\begin{tabular}{|c|c|c|c|c|c|c|c|c|}
\hline \multicolumn{9}{|c|}{ Quantitative and qualitative information pertinent to alternatives } \\
\hline \multirow[b]{2}{*}{$\begin{array}{l}\text { Criteria describing the } \\
\text { alternatives }\end{array}$} & \multirow[b]{2}{*}{ * } & \multirow[b]{2}{*}{$\begin{array}{l}\text { Measuring } \\
\text { units }\end{array}$} & \multirow[b]{2}{*}{ Weight } & \multicolumn{5}{|c|}{ Compared alternatives } \\
\hline & & & & $\begin{array}{l}\text { Alternative } \\
\text { No. } 1 \\
\text { (Daugèlių } \\
\text { str. 65) }\end{array}$ & $\begin{array}{l}\text { Alternative } \\
\quad \text { No. } 2 \\
\text { (L. Ivinskio } \\
\quad \text { str. 7) }\end{array}$ & $\begin{array}{c}\text { Alternative } \\
\text { No. } 3 \\
\text { (J. Basanavičiaus } \\
\text { str. } 3 \text { ) }\end{array}$ & $\begin{array}{l}\text { Alternative } \\
\text { No. } 4 \\
\text { (V. Daugèlių } \\
\text { str. 63) }\end{array}$ & $\begin{array}{l}\text { Alternative } \\
\text { No. } 5 \\
\text { (Jaunimo } \\
\text { str. } 4 \text { ) }\end{array}$ \\
\hline $\begin{array}{l}\text { Condition of heating } \\
\text { system }\end{array}$ & + & Points & 0.066 & 0.0132 & 0.0132 & 0.0132 & 0.0132 & 0.0132 \\
\hline $\begin{array}{l}\text { Condition of cold and hot } \\
\text { water supply engineering } \\
\text { system }\end{array}$ & + & Points & 0.0614 & 0.0095 & 0.0095 & 0.0142 & 0.0142 & 0.0142 \\
\hline $\begin{array}{l}\text { Condition of sewage } \\
\text { disposal engineering } \\
\text { system }\end{array}$ & + & Points & 0.0622 & 0.0096 & 0.0096 & 0.0144 & 0.0144 & 0.0144 \\
\hline $\begin{array}{l}\text { Condition of ventilation } \\
\text { system }\end{array}$ & + & Points & 0.0591 & 0.0091 & 0.0091 & 0.0136 & 0.0136 & 0.0136 \\
\hline $\begin{array}{l}\text { Condition of general } \\
\text { electrical engineering } \\
\text { system }\end{array}$ & + & Points & 0.0622 & 0.0096 & 0.0096 & 0.0144 & 0.0144 & 0.0144 \\
\hline $\begin{array}{l}\text { Condition of windows } \\
\text { and balcony doors in } \\
\text { apartments }\end{array}$ & + & Points & 0.0544 & 0.0117 & 0.0117 & 0.0117 & 0.0117 & 0.0078 \\
\hline \multicolumn{4}{|c|}{$\begin{array}{r}\text { Sums of weighted, normalized, maximizing alternative } \\
\text { indices (project "pluses") }\end{array}$} & 0.1619 & 0.1703 & 0.1894 & 0.1895 & 0.1793 \\
\hline \multicolumn{4}{|c|}{$\begin{array}{r}\text { Sums of weighted, normalized, maximizing alternative } \\
\text { indices (project "minuses") }\end{array}$} & 0.0123 & 0.0117 & 0.0275 & 0.0315 & 0.0268 \\
\hline \multicolumn{4}{|c|}{ Significance of the alternative } & 0.1947 & 0.2048 & 0.2041 & 0.2023 & 0.1944 \\
\hline \multicolumn{4}{|c|}{ Priority of the alternative } & 4 & 1 & 2 & 3 & 5 \\
\hline \multicolumn{4}{|c|}{ Utility degree of the alternative (\%) } & $95.08 \%$ & $100 \%$ & $99.65 \%$ & $98.79 \%$ & $94.91 \%$ \\
\hline
\end{tabular}

Note: ${ }^{\star}$ The sign $+(-)$ indicates that a greater (lesser) criterion value corresponds to a greater (lesser) significance for stakeholders

\subsection{Sensitivity analysis}

The sensitivity of the five alternatives (buildings) was analysed using an algorithm presented in Figure 2. Table 4 presents the initial decision matrix. Based on the parameters included in the matrix, random values uniformly distributed in the interval $x_{i j} \pm \lambda \%(\lambda=\overline{1.5}, i=\overline{1.5}, j=\overline{1.17})$ were generated and the calculations according to the COPRAS method were repeated 30 times. Table 5 summarises the calculation results.

Table 5. Sensitivity assessment according to uniform distribution law

\begin{tabular}{|l|c|c|c|c|c|}
\hline Alternatives & $A_{1}$ & $A_{2}$ & $A_{3}$ & $A_{4}$ & $A_{5}$ \\
\hline Initial ranks & 4 & 1 & 2 & 3 & 5 \\
\hline$\pm \lambda \%$ & \multicolumn{6}{|c|}{ Compliance with the initial assessment $\%$} \\
\hline $1 \%$ & 97 & 100 & 100 & 100 & 97 \\
\hline $2 \%$ & 83 & 97 & 97 & 100 & 83 \\
\hline $3 \%$ & 80 & 93 & 93 & 100 & 80 \\
\hline $4 \%$ & 73 & 80 & 80 & 100 & 73 \\
\hline $5 \%$ & 63 & 80 & 80 & 100 & 63 \\
\hline
\end{tabular}

The sensitivity analysis according to the normal distribution law $\mu=x_{i j}$ was then performed; random values under the condition $\sigma=\lambda \%(\lambda=\overline{1.5}, i=\overline{1.5}, j=\overline{1.17})$ were generated. In each deviation interval, 30 results were generated and calculations repeated. Table 6 summarises the calculation results.

The results of the sensitivity analysis suggest that the sensitivity of the results is, in both cases, rather low, with a small amount of random values. According to the model

Table 6. Sensitivity assessment according to normal distribution law

\begin{tabular}{|l|c|c|c|c|c|}
\hline Alternatives & $A_{1}$ & $A_{2}$ & $A_{3}$ & $A_{4}$ & $A_{5}$ \\
\hline Initial ranks & 4 & 1 & 2 & 3 & 5 \\
\hline$\pm \lambda \%$ & \multicolumn{5}{|c|}{ Compliance with the initial assessment \% } \\
\hline $1 \%$ & 93 & 100 & 100 & 100 & 93 \\
\hline $2 \%$ & 60 & 87 & 87 & 100 & 60 \\
\hline $3 \%$ & 43 & 83 & 80 & 93 & 43 \\
\hline $4 \%$ & 73 & 57 & 47 & 83 & 73 \\
\hline $5 \%$ & 57 & 60 & 57 & 93 & 57 \\
\hline
\end{tabular}


developed by the authors, the uniform distribution produces more sensitive results than the normal distribution.

Taking into account the specifics of the task, the normal distribution is a better option (the buildings to be refurbished were built in a similar period, similar materials and technologies were used). In this case, a higher sensitivity of the results to value changes provides better possibilities to carry out assessments of alternative projects when the differences of attribute values are minor.

\subsection{Selection of refurbishment measures and prediction of results}

Alternative 5 (Jaunimo st. 4, Kuršènai). In view of the current performance level of the building and looking at its energy efficiency, refurbishment measures were recommended. They are outlined in Table 7.

Predicted outcomes of refurbishment on energy efficiency are provided in Table 8 and GHG reduction in Table 9. It can be observed that energy efficiency savings can reach $62.92 \%$ and GHG emissions can be reduced by 51.27 tons per year.

Table 7. Proposed refurbishment measures for Alternative 5

\begin{tabular}{|c|c|c|c|}
\hline No. & Measure & Technology and parameters & Quantities \\
\hline 1. & $\begin{array}{l}\text { Insulation and improvement } \\
\text { of the façade walls (including } \\
\text { the cap) }\end{array}$ & $\begin{array}{l}\text { Insulation of the external walls with polystyrene } \\
\text { foam, a rendered façade. Finished with silicon or } \\
\text { silicate silicone plaster, paint containing anti-mould } \\
\text { additives. Insulation of the cap by embedding a heat } \\
\text { insulating layer ( } 1.2 \text { m deep) and waterproofing } \\
\text { layer, with finishing. } \\
\text { Paving restoration around the building. } \\
\text { Repair of the balcony floor slabs, reinforcement, } \\
\text { replacement of corroded railing elements. } \\
\text { Heat transfer coefficient for the walls and the cap } \\
U \leq 0.20\left(\mathrm{~W} / \mathrm{m}^{2} \mathrm{~K}\right) \text {. }\end{array}$ & $\begin{array}{l}\text { Number of renovated balconies: } 16 \\
\text { Insulated walls and embrasures: } \\
1092.80 \mathrm{~m}^{2} \\
\text { Insulated cap: } 177.17 \mathrm{~m}^{2}\end{array}$ \\
\hline 2. & $\begin{array}{l}\text { Insulation and improvement of } \\
\text { the roof }\end{array}$ & $\begin{array}{l}\text { Insulation of the roof, new roof covering. Roof heat } \\
\text { transfer coefficient } U \leq 0.16\left(\mathrm{~W} / \mathrm{m}^{2} \mathrm{~K}\right) \text {. Tin coating } \\
\text { for parapets and ventilation pipes. Restoration of the } \\
\text { lightning security system. }\end{array}$ & $\begin{array}{l}\text { Restored rainwater system: } 193.55 \mathrm{~m} \\
\text { Replaced roof covering: } 406.56 \mathrm{~m}^{2}\end{array}$ \\
\hline 3. & \multicolumn{3}{|c|}{ Replacement of windows and doors } \\
\hline 3.1. & $\begin{array}{l}\text { Replacement of the windows } \\
\text { and balcony doors (in the } \\
\text { apartments) }\end{array}$ & $\begin{array}{l}\text { Replacement of the apartment windows and balcony } \\
\text { doors with new triple-glazed windows, at least one } \\
\text { selective glass. Insulation of the entire window } \\
\text { perimeter with a special sealing tape. Installation of } \\
\text { new sills, finishing of embrasures. } \\
\text { Heat transfer coefficient for the windows } \\
U \leq 1.3\left(\mathrm{~W} / \mathrm{m}^{2} \mathrm{~K}\right) \text {. }\end{array}$ & $\begin{array}{l}\text { Number of replaced windows: } 26 \\
\text { Area: } 68.85 \mathrm{~m}^{2}\end{array}$ \\
\hline 3.2. & $\begin{array}{l}\text { Replacement of the windows } \\
\text { (in the landings) }\end{array}$ & $\begin{array}{l}\text { Replacement of the old windows with new openable } \\
\text { PVC windows, with finishing. Heat transfer } \\
\text { coefficient for the windows } U \leq 1.3\left(\mathrm{~W} / \mathrm{m}^{2} \mathrm{~K}\right) \text {. }\end{array}$ & $\begin{array}{l}\text { Number of replaced windows: } 20 \\
\text { Area: } 25.60 \mathrm{~m}^{2}\end{array}$ \\
\hline 3.3. & $\begin{array}{l}\text { Replacement of the windows } \\
\text { (in the cellar) }\end{array}$ & $\begin{array}{l}\text { Replacement of the cellar windows with new, } \\
\text { reinforced glass windows. Heat transfer coefficient } \\
\text { for the windows } U \leq 1.3\left(\mathrm{~W} / \mathrm{m}^{2} \mathrm{~K}\right) \text {. }\end{array}$ & $\begin{array}{l}\text { Number of replaced windows: } 9 \\
\text { Area: } 4.41 \mathrm{~m}^{2}\end{array}$ \\
\hline 3.4. & $\begin{array}{l}\text { Replacement of the external } \\
\text { doors }\end{array}$ & $\begin{array}{l}\text { Replacement of the external doors with new } \\
\text { hermetic ones. Heat transfer coefficient } \\
U \leq 1.6\left(\mathrm{~W} / \mathrm{m}^{2} \mathrm{~K}\right) \text {. }\end{array}$ & $\begin{array}{l}\text { Number of replaced doors: } 2 \\
\text { Area: } 5.06 \mathrm{~m}^{2}\end{array}$ \\
\hline 4. & $\begin{array}{l}\text { Cleaning of the ventilation and } \\
\text { recuperation systems }\end{array}$ & $\begin{array}{l}\text { Cleaning and disinfection of the ventilation ducts, } \\
\text { ventilation pipes raised higher. }\end{array}$ & Number of apartments: 24 \\
\hline 5. & \multicolumn{3}{|c|}{ Modernisation of the heating system (including water heating) } \\
\hline 5.1. & $\begin{array}{l}\text { Installation of balancing valves } \\
\text { on the racks }\end{array}$ & $\begin{array}{l}\text { Installation of automatic balancing valves and } \\
\text { isolation valves with the draining function on the } \\
\text { heating racks. Mounting of the devices on the } \\
\text { balancing valves for temperature control in the } \\
\text { reversible racks. }\end{array}$ & Number of balancing valves: 20 \\
\hline 5.2. & Insulation of the pipes & $\begin{array}{l}\text { Insulation of the heating system trunk pipelines by } \\
\text { wool shells with foil. }\end{array}$ & $\begin{array}{l}\text { Length of insulated pipelines: } \\
220.80 \mathrm{~m}\end{array}$ \\
\hline 5.3. & $\begin{array}{l}\text { Installation of sensors and } \\
\text { devices for individual heat } \\
\text { accounting }\end{array}$ & $\begin{array}{l}\text { Mounting of high-capacity two-way thermostatic } \\
\text { valves in the apartments, close to the radiators. } \\
\text { Factory-limited temperature range: } 16-28^{\circ} \mathrm{C} \text {. } \\
\text { Installation of rim narrowing. Removal of the old } \\
\text { regulatory mechanisms in tees, changing to new } \\
\text { (standard) tees. }\end{array}$ & Number of thermostatic valves: 84 \\
\hline
\end{tabular}


Table 8. Predicted energy savings after refurbishment for Alternative 5

\begin{tabular}{|c|c|c|c|}
\hline & \multirow{2}{*}{$\begin{array}{c}\text { Units of } \\
\text { measurement }\end{array}$} & \multicolumn{2}{|c|}{ Amount } \\
\hline & & Current situation & Prospective \\
\hline Building energy performance class & Class & $\mathrm{E}$ & $\mathrm{C}$ \\
\hline $\begin{array}{l}\text { Computational home heating energy consumption for space } \\
\text { heating, including by energy-saving measures: }\end{array}$ & \multirow[t]{8}{*}{$\mathrm{kWh} / \mathrm{m}^{2} /$ year } & 326.57 & 121.08 \\
\hline - Heat loss through the walls of the building & & 85.01 & 13.39 \\
\hline - Heat loss through the roof of the building & & 28.62 & 5.39 \\
\hline $\begin{array}{l}\text { - Heat loss through the building's ceilings above unheated } \\
\text { basements and cellars }\end{array}$ & & 10.93 & 10.93 \\
\hline - Heat loss through the walls bordering the ground & & 0.00 & 0.00 \\
\hline - Heat loss through the windows of the building & & 48.75 & 37.91 \\
\hline - Heat loss through the building's thermal bridges & & 51.92 & 22.86 \\
\hline - The energy consumption of the building ventilation & & 24.04 & 24.04 \\
\hline $\begin{array}{l}\text { Computational thermal energy cost savings compared to the } \\
\text { current situation data }\end{array}$ & percentage & - & 62.92 \\
\hline GHG $\left(\mathrm{CO}_{2}\right.$ eq. $)$ reduction & tons/year & - & 51.27 \\
\hline
\end{tabular}

Note: ${ }^{*}$ - Calculated savings are counted on the basis of regulation STR 2.01.09: 2012 "Energy performance of buildings. The energy performance certification" and from real may vary by about $25 \%$

Table 9. Reduction of greenhouse gas (GHG) emissions $\left(\mathrm{CO}_{2}\right.$ eq.) for Alternative $5^{\star}$

\begin{tabular}{|l|c|c|c|}
\hline \multicolumn{1}{|c|}{ The annual thermal energy consumption } & MWh/year & (A) & 220.04 \\
\hline Emission factor value & $\mathrm{t} \mathrm{CO}_{2}$ eq./MWh & (B) & 0.233 \\
\hline The annual reduction of GHG emissions & $\mathrm{t} \mathrm{CO}_{2}$ eq. $/$ year & (C) $=(\mathrm{A}) \times(\mathrm{B})$ & (D) \\
\hline Project assessment period & years & (E) $=(\mathrm{C}) \times(\mathrm{D})$ & 125.00 \\
\hline Total reduction of GHG emissions & $\mathrm{t} \mathrm{CO}_{2}$ eq. & 1281.71 \\
\hline
\end{tabular}

Note: * The calculations follow the Greenhouse Gas Emissions Reduction Assessment Methodology under the Climate Change Special Programme (2014). When the heat is supplied centrally, the emission factor value equals 0.233 tonnes CO2eqv/MWh. According to the methodology, the "embodied energy" and related embodied "environmental impact" of the new/added components (e.g. new windows, external insulation) and the required GHGemissions from manufacturing are not estimated due to the lack of data.

Alternative 1 (Daugèlių st. 65, Kuršènai). In view of the current performance level of the building and looking at its energy efficiency, refurbishment measures were recommended. They are outlined in Table 10.
Predicted outcomes of refurbishment on energy efficiency are provided in Table 11 and GHG reduction in Table 12. It can be observed that energy efficiency savings can reach $64.76 \%$ and GHG emissions can be reduced by 77.83 tons per year.

Table 10. Proposed refurbishment measures for Alternative 1

\begin{tabular}{|l|l|l|l|}
\hline No. & \multicolumn{1}{|c|}{ Measure } & \multicolumn{1}{|c|}{ Technology and parameters } & \multicolumn{1}{|c|}{ Quantities } \\
\hline 1. & $\begin{array}{l}\text { Insulation and improvement } \\
\text { of the façade walls } \\
\text { (including the cap) }\end{array}$ & $\begin{array}{l}\text { Insulation of the external walls with polystyrene foam, } \\
\text { cladding with decorative panels. Insulation of the cap by } \\
\text { embedding a heat insulating layer } \\
(1.2 \mathrm{~m} \text { deep) and waterproofing layer, with finishing. } \\
\text { Insulation of the pavement, paving restoration around the } \\
\text { building. } \\
\text { Minor repair of the balconies, the reinforcement of their } \\
\text { structures. } \\
\text { Heat transfer coefficient for the walls and the cap } \\
U \leq 0.20 \text { (W/m² }) .\end{array}$ & $\begin{array}{l}\text { Number of renovated balconies: } \\
\text { Insulated walls and embrasures: } \\
2,785.57 \mathrm{~m}^{2} \\
\text { Insulated cap: } 399.88 \mathrm{~m}^{2}\end{array}$ \\
\hline 2. & $\begin{array}{l}\text { Insulation and improvement } \\
\text { of the roof }\end{array}$ & $\begin{array}{l}\text { Insulation of the roof, new roof covering. Roof heat } \\
\left.\text { transfer coefficient } U \leq 0.16 \text { (W/m } \mathrm{m}^{2} \mathrm{~K}\right) . \text { Tin coating for } \\
\text { parapets and ventilation pipes. Restoration of the lightning } \\
\text { security system. }\end{array}$ & $\begin{array}{l}\text { Replaced roof covering: } 748.48 \\
\mathrm{~m}^{2}\end{array}$ \\
\hline
\end{tabular}


End of Table 10

\begin{tabular}{|c|c|c|c|}
\hline No. & Measure & Technology and parameters & Quantities \\
\hline 3. & \multicolumn{3}{|c|}{ Replacement of windows and doors } \\
\hline 3.1. & $\begin{array}{l}\text { Replacement of the } \\
\text { windows and balcony doors } \\
\text { (in the apartments) }\end{array}$ & $\begin{array}{l}\text { Replacement of the apartment windows and balcony doors } \\
\text { with new triple-glazed windows, at least one selective glass. } \\
\text { Insulation of the entire window perimeter with a special } \\
\text { sealing tape. Installation of new sills, finishing of embrasures. } \\
\left.\text { Heat transfer coefficient for the windows } U \leq 1.3 \text { (W/ } \mathrm{m}^{2} \mathrm{~K}\right) \text {. }\end{array}$ & $\begin{array}{l}\text { Number of replaced windows: } 46 \\
\text { Area: } 98.66 \mathrm{~m}^{2}\end{array}$ \\
\hline 3.2 . & $\begin{array}{l}\text { Replacement of the } \\
\text { windows (in the landings) }\end{array}$ & $\begin{array}{l}\text { Replacement of the old windows with new openable PVC } \\
\text { windows, with finishing. Heat transfer coefficient for the } \\
\text { windows } U \leq 1.3\left(\mathrm{~W} / \mathrm{m}^{2} \mathrm{~K}\right) \text {. }\end{array}$ & $\begin{array}{l}\text { Number of replaced windows: } 24 \\
\text { Area: } 35.55 \mathrm{~m}^{2}\end{array}$ \\
\hline 3.3 . & $\begin{array}{l}\text { Replacement of the } \\
\text { windows (in the cellar). }\end{array}$ & $\begin{array}{l}\text { Replacement of the cellar windows with new, reinforced } \\
\text { glass windows. Heat transfer coefficient for the windows } U \\
\leq 1.3\left(\mathrm{~W} / \mathrm{m}^{2} \mathrm{~K}\right) \text {. }\end{array}$ & $\begin{array}{l}\text { Number of replaced windows: } 20 \\
\text { Area: } 13.2 \mathrm{~m}^{2}\end{array}$ \\
\hline 3.4 . & $\begin{array}{l}\text { Replacement of the external } \\
\text { doors }\end{array}$ & $\begin{array}{l}\text { Replacement of the external doors with new hermetic } \\
\text { ones. Heat transfer coefficient } U \leq 1.6\left(\mathrm{~W} / \mathrm{m}^{2} \mathrm{~K}\right) \text {. }\end{array}$ & $\begin{array}{l}\text { Number of replaced doors: } 13 \\
\text { Area: } 34.58 \mathrm{~m}^{2}\end{array}$ \\
\hline 4. & $\begin{array}{l}\text { Cleaning of the ventilation } \\
\text { and recuperation systems }\end{array}$ & $\begin{array}{l}\text { Cleaning and disinfection of the ventilation ducts, } \\
\text { ventilation pipes raised higher. }\end{array}$ & Number of apartments: 45 \\
\hline 5. & \multicolumn{3}{|c|}{ Modernisation of the heating system (including water heating) } \\
\hline 5.1. & $\begin{array}{l}\text { Installation of balancing } \\
\text { valves on the racks }\end{array}$ & $\begin{array}{l}\text { Installation of automatic balancing valves and isolation } \\
\text { valves with the draining function on the heating racks. } \\
\text { Mounting of the devices on the balancing valves for } \\
\text { temperature control in the reversible racks. } \\
\text { Installation of a hot water supply system with thermal } \\
\text { circulation valves, equipped with a disinfection module and } \\
\text { a thermometer for temperature balancing in all the racks. } \\
\text { Replacement of the hot water distribution valves with new } \\
\text { ball-type ones. }\end{array}$ & Number of balancing valves: 38 \\
\hline 5.2 . & Insulation of the pipes & $\begin{array}{l}\text { Insulation of the heating system trunk pipelines by wool } \\
\text { shells with foil. }\end{array}$ & $\begin{array}{l}\text { Length of insulated heating pipes: } \\
363.29 \mathrm{~m} \\
\text { Length of insulated hot water } \\
\text { supply pipes: } 413.05 \mathrm{~m}\end{array}$ \\
\hline 5.3. & $\begin{array}{l}\text { Replacement of the heating } \\
\text { devices and pipelines }\end{array}$ & $\begin{array}{l}\text { Replacement of the existing heating system with a two- } \\
\text { pipe system; replacement of the pipelines and radiators. }\end{array}$ & $\begin{array}{l}\text { Number of replaced devices: } 151 \\
\text { Length of new pipeline: } 2,230.06 \mathrm{~m}\end{array}$ \\
\hline 5.4 . & $\begin{array}{l}\text { Installation of sensors and } \\
\text { devices for individual heat } \\
\text { accounting }\end{array}$ & $\begin{array}{l}\text { Mounting of high-capacity two-way thermostatic valves } \\
\text { in the apartments, close to the radiators. Factory-limited } \\
\text { temperature range: from } 16^{\circ} \mathrm{C} \text {. } \\
\text { Installation of devices for heat accounting and fee } \\
\text { charging, software for remote data reading. }\end{array}$ & $\begin{array}{l}\text { Number of thermostatic valves: } \\
151 \\
\text { Number of sensors: } 151\end{array}$ \\
\hline
\end{tabular}

Table 11. Predicted energy savings after refurbishment for Alternative 1

\begin{tabular}{|c|c|c|c|}
\hline \multirow{2}{*}{ Indicators } & \multirow{2}{*}{$\begin{array}{l}\text { Units of } \\
\text { measurement }\end{array}$} & \multicolumn{2}{|c|}{ Amount } \\
\hline & & Current situation & Prospective \\
\hline Building energy performance class & Class & $\mathrm{D}$ & $\mathrm{C}$ \\
\hline $\begin{array}{l}\text { Computational home heating energy consumption for space } \\
\text { heating, including by energy-saving measures: }\end{array}$ & \multirow[t]{8}{*}{$\mathrm{kWh} / \mathrm{m}^{2} /$ year } & 190.73 & 67.22 \\
\hline - Heat loss through the walls of the building & & 70.65 & 10.89 \\
\hline - Heat loss through the roof of the building & & 22.29 & 4.20 \\
\hline $\begin{array}{l}\text { - Heat loss through the building's ceilings above unheated } \\
\text { basements and cellars }\end{array}$ & & 8.51 & 8.51 \\
\hline - Heat loss through the walls bordering the ground & & 0.00 & 0.00 \\
\hline - Heat loss through the windows of the building & & 32.22 & 27.13 \\
\hline - Heat loss through the building's thermal bridges & & 32.38 & 12.76 \\
\hline - The energy consumption of the building ventilation & & 24.04 & 24.04 \\
\hline $\begin{array}{l}\text { Computational thermal energy cost savings compared to the } \\
\text { current situation data }\end{array}$ & percentage & - & 64.76 \\
\hline GHG $\left(\mathrm{CO}_{2}\right.$ eq. $)$ reduction & tons/year & - & 77.83 \\
\hline
\end{tabular}

Note: * Calculated savings are counted on the basis of regulation STR 2.01.09: 2012 "Energy performance of buildings. The energy performance certification" and from real may vary by about $25 \%$ 
Table 12. Reduction of greenhouse gas (GHG) emissions $\left(\mathrm{CO}_{2}\right.$ eq.) for Alternative $1^{*}$

\begin{tabular}{|l|c|c|c|}
\hline \multicolumn{1}{|c|}{ The annual thermal energy consumption } & MWh/year & (A) & 334.03 \\
\hline Emission factor value & $\mathrm{t} \mathrm{CO}_{2}$ eq./MWh & (B) & 0.233 \\
\hline The annual reduction of GHG emissions & $\mathrm{t} \mathrm{CO}_{2}$ eq. $/$ year & (C) $=$ (A) $\mathrm{x}$ (B) & 77.83 \\
\hline Project assessment period & years & (D) & 25.00 \\
\hline Total reduction of GHG emissions & $\mathrm{t} \mathrm{CO}_{2}$ eq. & (E) $=$ (C) $\mathrm{x}$ (D) & 1945.72 \\
\hline
\end{tabular}

Note: * The calculations follow the Greenhouse Gas Emissions Reduction Assessment Methodology under the Climate Change Special Programme (2014). When the heat is supplied centrally, the emission factor value equals 0.233 tonnes CO2eqv/MWh. According to the methodology, the "embodied energy" and related embodied "environmental impact" of the new/added components (e.g. new windows, external insulation) and the required GHGemissions from manufacturing are not estimated due to the lack of data.

\section{Conclusions}

The selection of buildings for refurbishment is a multiobjective problem and it should be based on integrated assessment of the current performance of the buildings. Any detailed assessment of the performance of old buildings must consider technical and functional obsolescence criteria. It follows, therefore, that building performance assessment requires a multidisciplinary and multi-criteria approach.

The methodology for the assessment of apartment building performance proposed by the authors is based on COPRAS, a multiple criteria method, and consists of eight interrelated stages. This methodology enables an integrated assessment of apartment building performance, the selection of the worst performing buildings and appropriate measures for their refurbishment, and an assessment of potential results.

A case study in Šiauliai district, Lithuania, illustrated the proposed methodology in use, with five apartment buildings as alternatives. The results of the multiple criteria assessment suggest that the best performing is Alternative 2 (L. Ivinskio st. 7, Kuršènai), while Alternative 5 (Jaunimo st. 4, Kuršènai) and Alternative 1 (Daugèlių st. 65, Kuršenai) are the worst performing. Sensitivity analysis according to uniform and normal distributions' laws revealed that assessments were accurate enough for further applications. Refurbishment measures were proposed for the worst performing buildings, and potential outcomes estimated. In general, energy consumption of these buildings can be reduced by more than $60 \%$ and GHG emissions by more than $50 \%$.

For more accurate results, the proposed model could be extended by including more MCDA methods as the other MCDA methods may be equally good depending on specific application. The sensitivity analysis of the attribute significances also could be included. Moreover, the calculations of GHG emissions could include the assessment of the "embodied energy" and the related embodied "environmental impact" of the new/added components (e.g. new windows, external insulation) and the required GHG-emissions from manufacturing. These are seen as the main limitations of this research and challenging topics for future research to be performed by the authors.

\section{References}

Baek, C.-H., \& Park, S.-H. (2012). Changes in renovation policies in the era of sustainability. Energy and Buildings, 47, 485-496. https://doi.org/10.1016/j.enbuild.2011.12.028

Banaitiene, N., Banaitis, A., Kaklauskas, A., \& Zavadskas, E. K. (2008). Evaluating the life cycle of a building: a multivariant and multiple criteria approach. Omega - International Journal of Management Science, 36(3), 429-441.

https://doi.org/10.1016/j.omega.2005.10.010

Bayer, C., Gamble, M., Gentry, R., \& Joshi, S. (2010). A guide to life cycle assessment of buildings. The American Institute of Architects.

Biekša, D., Šiupšinskas, G., Martinaitis, V., \& Jaraminienè, E. (2011). Energy efficiency challenges in multi-apartment building renovation in Lithuania. Journal of Civil Engineering and Management, 17(4), 467-475.

https://doi.org/10.3846/13923730.2011.622408

Brown, N. W. O., Malmqvist, T., Bai, W., \& Molinari, M. (2013). Sustainability assessment of renovation packages for increased energy efficiency for multi-family buildings in Sweden. Building and Environment, 61, 140-148.

https://doi.org/10.1016/j.buildenv.2012.11.019

Caliskan, H. (2015). Thermodynamic and environmental analyses of biomass, solar and electrical energy options based building heating applications. Renewable and Sustainable Energy Reviews, 43, 1016-1034.

https://doi.org/10.1016/j.rser.2014.11.094

Cegan, J. C., Filion, A. M., Keisler, J. M., \& Linkov, I. (2017). Trends and applications of multi-criteria decision analysis in environmental sciences: literature review. Environment Systems and Decisions, 37(2), 123-133.

https://doi.org/10.1007/s10669-017-9642-9

Cellura, M., Campanella, L., Ciulla, G., Guarino, F., Lo Brano, V., Nardi Cesarini, D., \& Orioli, A. (2011). The redesign of an Italian building to reach net-zero energy performances: a case study of the SHC Task 40 - ECBCS Annex 52. ASHRAE Transactions, 117, Part 2, 331-339.

Chatterjee, P., Athawale, V. M., \& Chakraborty, S. (2011). Materials selection using complex proportional assessment and evaluation of mixed data methods. Materials \& Design, 32(2), 851-860. https://doi.org/10.1016/j.matdes.2010.07.010

Chau, C. K., Hui, W. K., Ng, W. Y., \& Powell, G. (2012). Assessment of $\mathrm{CO} 2$ emissions reduction in high-rise concrete office buildings using different material use options. Resources, Conservation and Recycling, 61, 22-34. https://doi.org/10.1016/j.resconrec.2012.01.001

Ciulla, G., Lo Brano, V., \& Orioli, A. (2010). A criterion for the assessment of the reliability of ASHRAE conduction transfer 
function coefficients. Energy and Buildings, 42(9), 1426-1436. https://doi.org/10.1016/j.enbuild.2010.03.012

Di Sivo, M., \& Ladiana, D. (2011). Decision-support tools for municipal infrastructure maintenance management. Procedia Computer Science, 3, 36-41.

https://doi.org/10.1016/j.procs.2010.12.007

Galvin, R. (2012). German Federal policy on thermal renovation of existing homes: a policy evaluation. Sustainable Cities and Society, 4, 58-66. https://doi.org/10.1016/j.scs.2012.05.003

Hopfe, C. J., Augenbroe, G. L. M., \& Hensen, J. L. M. (2013). Multi-criteria decision making under uncertainty in building performance assessment. Building and Environment, 69, 8190. https://doi.org/10.1016/j.buildenv.2013.07.019

Huang, I. B., Keisler, J., \& Linkov, I. (2011). Multi-criteria decision analysis in environmental sciences: ten years of applications and trends. Science of The Total Environment, 409(19), 3578-3594. https://doi.org/10.1016/j.scitotenv.2011.06.022

Ibn-Mohammed, T., Greenough, R., Taylor, S., Ozawa-Meida, L., \& Acquaye, A. (2014). Integrating economic considerations with operational and embodied emissions into a decision support system for the optimal ranking of building retrofit options. Building and Environment, 72, 82-101.

https://doi.org/10.1016/j.buildenv.2013.10.018

Juan, Y.-K., Kim, J. H., Roper, K., \& Castro-Lacouture, D. (2009). GA-based decision support system for housing condition assessment and refurbishment strategies. Automation in Construction, 18(4), 394-401. https://doi.org/10.1016/j.autcon.2008.10.006

Kabak, M., Köse, E., Kırılmaz, O., \& Burmaoğlu, S. (2014). A fuzzy multi-criteria decision making approach to assess building energy performance. Energy and Buildings, 72, 382389. https://doi.org/10.1016/j.enbuild.2013.12.059

Kaklauskas, A. (1999). Multiple criteria decision support of building life cycle (60 p.). Research Report presented for Habilitation. Vilnius: Technika.

Kaklauskas, A., Tupenaitė, L., Kanapeckienė, L., \& Naimavičienė, J. (2013). Knowledge-based model for standard housing renovation. Procedia Engineering, 57, 497-503. https://doi.org/10.1016/j.proeng.2013.04.064

Kaklauskas, A., Zavadskas, E. K., \& Galinienè, B. (2008). A building's refurbishment knowledge-based decision support system. International Journal of Environment and Pollution, 35(2/3/4), 237-249. https://doi.org/10.1504/IJEP.2008.021358

Kaklauskas, A., Zavadskas, E. K., \& Raslanas, S. (2005). Multivariant design and multiple criteria analysis of building refurbishments. Energy and Buildings, 37(4), 361-372. https://doi.org/10.1016/j.enbuild.2004.07.005

Kaklauskas, A., Zavadskas, E. K., Raslanas, S., Ginevičius, R., Komka, A., \& Malinauskas, P. (2006). Selection of low-e windows in retrofit of public buildings by applying multiple criteria method COPRAS: a Lithuanian case. Energy and Buildings, 38(5), 454-462. https://doi.org/10.1016/j.enbuild.2005.08.005

Kaklauskas, A., Zavadskas, E. K., Lepkova, N., Raslanas, S., Šliogerienė, J., Bartkienè, L., Pečiūrè, L., \& Rimkuvienè, S. (2015). Multiple criteria analysis of the life cycle of the built environment (448 p.). Vilnius: Technika.

Kanapeckienè, L., Kaklauskas, A., Zavadskas, E. K., \& Raslanas, S. (2011). Method and system for multi-attribute market value assessment in analysis of construction and retrofit projects. Expert Systems with Applications, 38(11), 14196-14207. https://doi.org/10.1016/j.eswa.2011.04.232

Kragh, J., \& Rose, J. (2011). Energy renovation of single-family houses in Denmark utilising long-term financing based on equity. Applied Energy, 88(6), 2245-2253.

https://doi.org/10.1016/j.apenergy.2010.12.049
Kurth, M. H., Larkin, S., Keisler, J. M., \& Linkov, I. (2017). Trends and applications of multi-criteria decision analysis: use in government agencies. Environment Systems and Decisions, 37(2), 134-143. https://doi.org/10.1007/s10669-017-9644-7

Lasvaux, S., Favre, D., Périsset, B., Bony, J., Hildbrand, C., \& Citherlet, S. (2015). Life Cycle Assessment of energy related building renovation: methodology and case study. Energy Procedia, 78, 3496-3501. https://doi.org/10.1016/j.egypro.2016.10.132

Lietuvos aplinkos apsaugos investicijų fondas. (2014). Greenhouse gas emissions reduction assessment methodology under the climate change special programme 2014. Retrieved from http://www.laaif.lt/lt/klimato-kaitos-specialioji-programa/ismetamu-siltnamio-efekta-sukelianciu-duju-kiekio-sumazinimo-vertinimo-metodika/ (in Lithuanian).

Linkov, I., \& Moberg, E. (2012). Multi-criteria decision analysis: environmental applications and case studies. New York: CRC Press.

Mahapatra, K., Gustavsson, L., Haavik, T., Aabrekk, S., Svendsen, S., Vanhoutteghem, L., Paiho, S., \& Ala-Juusela, M. (2013). Business models for full service energy renovation of singlefamily houses in Nordic countries. Applied Energy, 112, 15581565. https://doi.org/10.1016/j.apenergy.2013.01.010

Medineckiené, M., \& Björk, F. (2011). Owner preferences regarding renovation measures - the demonstration of using multi-criteria decision makin. Journal of Civil Engineering and Management, 17(2), 284-295.

https://doi.org/10.3846/13923730.2011.582380

Mlecnik, E., Kondratenko, I., Cré, J., Vrijders, J., Degraeve, P., van der Have, J. A., Haavik, T., Aabrekk, S. A., Grøn, M., Hansen, S., Svendsen, S., Stenlund, O., \& Paiho, S. (2012). Collaboration opportunities in advanced housing renovation. Energy Procedia, 30, 1380-1389. https://doi.org/10.1016/j.egypro.2012.11.152

Mun, J. (Ed.). (2006). Modeling risk: applying Monte Carlo simulation, strategic real options, stochastic forecasting, and portfolio optimization. New Jersey: John Wiley \& Sons, Inc.

Nemry, F., Uihlein, A., Colodel, C. M., Wetzel, C., Braune, A., Wittstock, B., Hasan, I., Kreißig, J., Gallon, N., Niemeier, S., \& Frech, Y. (2010). Options to reduce the environmental impacts of residential buildings in the European Union -Potential and costs. Energy and Buildings, 42(7), 976-984. https://doi.org/10.1016/j.enbuild.2010.01.009

Nicolae, B., \& George-Vlad, B. (2015). Life cycle analysis in refurbishment of the buildings as intervention practices in energy saving. Energy and Buildings, 86, 74-85. https://doi.org/10.1016/j.enbuild.2014.10.021

Ochoa, C. E., \& Capeluto, I. G. (2015). Decision methodology for the development of an expert system applied in an adaptable energy retrofit façade system for residential buildings. Renewable Energy, 78, 498-508.

https://doi.org/10.1016/j.renene.2015.01.036

Ouyang, J., Wang, C., Li, H., \& Hokao, K. (2011). A methodology for energy-efficient renovation of existing residential buildings in China and case study. Energy and Buildings, 43, 22032210. https://doi.org/10.1016/j.enbuild.2011.05.005

Rasiulis, R., Ustinovichius, L., Vilutienè, T., \& Popov, V. (2016). Decision model for selection of modernization measures: public building case. Journal of Civil Engineering and Management, 22(1), 124-133.

https://doi.org/10.3846/13923730.2015.1117018

Preparation procedure for renovation (modernization) projects, approved by the Minister of Environment of the Republic of Lithuania, 10 November 2009, Order No. D1-677. Valstybes Žinios, 2009, No. 136-5963; 2011, No. 139-6563; 2014, No. D1-365) (in Lithuanian). 
Rezaie, B., Dincer, I., \& Esmailzadeh, E. (2013). Energy options for residential buildings assessment. Energy Conversion and Management, 65, 637-646.

https://doi.org/10.1016/j.enconman.2012.09.008

Sakalauskas, L., \& Žilinskas, K. (2006). Application of statistical criteria to optimality testing in stochastic programming. Technological and Economic Development of Economy, 12(4), 314-320.

Saltelli, A., Ratto, M., Andres, T., Campolongo, F., Cariboni, J., Gatelli, D., Saisana, M., \& Tarantola, S. (2008). Global sensitivity analysis. West Sussex: John Wiley \& Sons, Ltd.

Šiožinyte, E., Antuchevičiene, J., \& Kutut, V. (2014). Upgrading the old vernacular building to contemporary norms: multiple criteria approach. Journal of Civil Engineering and Management, 20(2), 291-298. https://doi.org/10.3846/13923730.2014.904814

STR 2.01.09: 2012 "Energy performance of buildings. The energy performance certification". Lithuanian Standard.

Tupenaite, L. (2010). Multiple criteria assessment of the built environment renovation projects ( $\mathrm{PhD}$ dissertation). Vilnius: Vilnius Gediminas Technical University.

Tupènaitè, L., Zavadskas, E. K., Kaklauskas, A., Turskis, Z., \& Seniut, M. (2010). Multiple criteria assessment of alternatives for built and human environment renovation. Journal of Civil Engineering and Management, 16(2), 257-266. https://doi.org/10.3846/jcem.2010.30

Uihlein, A., \& Eder, P. (2010). Policy options towards an energy efficient residential building stock in the EU-27. Energy and Buildings, 42(6), 791-798.

https://doi.org/10.1016/j.enbuild.2009.11.016
Uzomah, V., Scholz, M., \& Almuktar, S. (2014). Rapid expert tool for different professions based on estimated ecosystem variables for retrofitting of drainage systems. Computers, Environment and Urban Systems, 44, 1-14.

https://doi.org/10.1016/j.compenvurbsys.2013.10.008

Vilcekova, S., \& Kridlova Burdova, E. (2014). Multi-criteria analysis of building assessment regarding energy performance using a life-cycle approach. International Journal of Energy and Environmental Engineering, 5, 83. https://doi.org/10.1007/s40095-014-0083-7

Zavadskas, E. K., \& Antuchevičienè, J. (2007). Multiple criteria evaluation of rural building's regeneration alternatives. Building and Environment, 42, 436-451. https://doi.org/10.1016/j.buildenv.2005.08.001

Zavadskas, E. K., \& Kaklauskas, A. (1996). Pastatu sistemotechninis ivvertinimas [Multicriteria evaluation of buildings]. Vilnius: Technika (in Lithuanian).

Zavadskas, E. K., Turskis, Z., \& Kildienè, S. (2014). State of art overviews on MCDM/MADM methods. Technological and Economic Development of Economy, 20(1), 165-179. https://doi.org/10.3846/20294913.2014.892037

Zhang, X., \& Wang, F. (2015). Life-cycle assessment and control measures for carbon emissions of typical buildings in China. Building and Environment, 86, 89-97. https://doi.org/10.1016/j.buildenv.2015.01.003 